\title{
Primary Diffuse Large B-cell Lymphoma of the Breast: Treatment and Long-Term Outcome of Two Cases
}

\begin{abstract}
Primary breast lymphoma (PBL) is a rare form of extranodal non-Hodgkin's lymphoma (NHL). It accounts for $<0.5 \%$ of all breast malignancies and $2 \%$ extranodal NHL. Diffuse large B-cell lymphoma (DLBCL) is the most common histological subtype. We report three cases of PBL diagnosed and treated at our center. The clinical records of three female patients diagnosed with PBL from 2004 to 2015 were reviewed. Two patients had DLBCL, and the third patient had anaplastic large cell (ALCL) NHL. The mean age at presentation was 56 years. One patient with DLBCL was treated with cyclophosphamide, doxorubicin, vincristine, and prednisolone (CHOP) chemotherapy and the second patient with rituximab plus CHOP chemotherapy. Both the patients showed complete response and have had a disease-free survival of 84 and 96 months, respectively. The third patient with ALCL refused further treatment after confirmation of diagnosis. PBL-DLBCL can be successful treated with chemotherapy, and long-term survival is similar to nodal NHL.
\end{abstract}

Keywords: Breast lymphoma, chemotherapy, diffuse large b-cell lymphoma, rituximab

\section{Introduction}

Primary breast lymphoma (PBL) is a rare form of extranodal non-Hodgkin's lymphoma (NHL) and accounts for $<0.5 \%$ of all breast malignancies It represents $<1 \%$ of all NHL and $2.2 \%$ of extranodal NHL. ${ }^{[1,2]}$ It is postulated that PBL originates in the lymphatic tissue present within the breast adjacent to ducts and lobules or from intramammary nodes. ${ }^{[3,4]}$ Wiseman and Liao, ${ }^{[5]}$ first proposed the diagnostic criteria for PBL as follows

1. The clinical site of presentation is the breast

2. A history of previous lymphoma or evidence of widespread disease is absent at diagnosis

3. Lymphoma is demonstrated with close association to breast tissue in the pathologic specimen

4. Ipsilateral lymph node may be involved if they develop simultaneously with the primary breast tumor.

This definition of PBL comprises only tumor that are Stage I (lymphoma limited to the breast) and Stage II (lymphoma

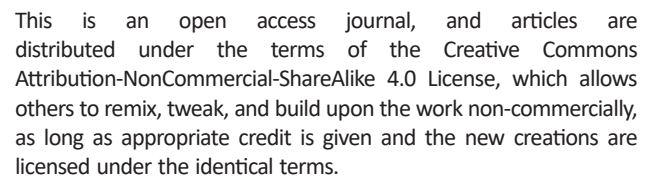
others to remix, tweak, and build upon the work non-commercially, as long as appropriate credit is given and the new creations are licensed under the identical terms.

For reprints contact: WKHLRPMedknow_reprints@wolterskluwer.com limited to the breast and axillary lymph nodes), excluding those tumor that may have originated at nonbreast sites. Surgery, radiotherapy, and chemotherapy have been used alone or in combination in its management. ${ }^{[6]}$ However, the optimal therapy of PBL still remains undefined.

We report three cases of PBL which we have diagnosed and managed. The issues involved in its diagnosis and management are discussed in this communication.

\section{Materials and Methods}

In a retrospective analysis, the medical records of all diagnosed with NHL between the period January 2004 and December 2014 at the Department of Hematology were searched for cases of PBL.

Three cases were diagnosed to have PBL as per the criteria defined by Wiesman and Liao. ${ }^{[5]}$ The diagnosis was established on histopathological evidence of tumor specimen based on the WHO nomenclature. ${ }^{[7]}$ All the patients underwent computed tomography (CT) of the chest, abdomen, and pelvis and bone marrow biopsy for staging of the disease as per the Ann Arbor staging system. ${ }^{[8]}$

How to cite this article: Kashyap R, Kumar P, Lal H, Rao RN. Primary diffuse large B-cell lymphoma of the breast: Treatment and long-term outcome of two cases. Indian J Med Paediatr Oncol 2020;41:78-81.

\section{Rajesh Kashyap', Pradeep Kumar', Hira Lal' ${ }^{2}$, Ram Naval Rao ${ }^{3}$}

${ }^{1}$ Department of Hematology, Sanjay Gandhi Postgraduate Institute of Medical Sciences, Lucknow, Uttar Pradesh, India, ${ }^{2}$ Department of Radio Diagnosis, Sanjay Gandhi Postgraduate Institute of Medical Sciences, Lucknow, Uttar Pradesh, India,

${ }^{3}$ Department of Pathology, Sanjay Gandhi Postgraduate Institute of Medical Sciences, Lucknow, Uttar Pradesh, India

Submitted: 06-Jan-2018 Accepted in Revised Form: 18-Apr-2018

Published: 24-Apr-2020

Address for correspondence: Dr. Rajesh Kashyap, Department of Hematology, Sanjay Gandhi Postgraduate Institute of Medical Sciences, Rae Bariely Road, Lucknow - 226014 , Uttar Pradesh, India.

E-mail: rajkashyapmd@yahoo. co.in

Access this article online

Website: www.ijmpo.org

DOI: 10.4103/ijmpo.ijmpo_4_18 Quick Response Code:
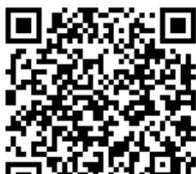

ㅁiffint 


\section{Results}

The clinical and laboratory findings and treatment outcome are summarized in Tables 1 and 2.

\section{Clinical and laboratory features}

Three multiparous postmenopausal females were diagnosed with PBL. The mean age at presentation was 56 (range 50-66) years. All three patients presented with unilateral breast mass. Two patients (Cases 2 and 3) swelling in the right breast and the third case (case1) had a left breast mass. The average time from onset of symptoms to presentation at the hospital was 6 (range 1-12) months. None of the patients had any symptoms or signs of local inflammation or tumor infiltration (local erythema, puckering of the skin, or nipple retraction) at presentation. "B" symptoms were reported in only two patients. None of the three patients had any clinical features to suggest central nervous system involvement (CNS) at the time of initial presentation. The clinical stage of the disease was IIE in all the three cases [Table 1].

Radiological evaluation showed the disease localized to the breast tissue only; there was no evidence of systemic disease [Figure $1 \mathrm{a}$ and b]. On histopathological examination (HPE), two patients had CD 20 positive diffuse large B cell lymphoma (DLBCL) [Figures 2 and 3]. The third patient (Case 3) had anaplastic large cell lymphoma (ALCL).

\section{Treatment and outcome}

Case 1 underwent modified radical mastectomy along with axillary lymph node resection. Postoperatively, the patient received a total of 6 cycles of cyclophosphamide, doxorubicin, vincristine, and prednisolone (CHOP) chemotherapy, No radiotherapy was given, and the patient achieved complete remission (CR) after the end of the treatment. Case 2 underwent a core tissue biopsy for the evaluation of the right breast mass. The biopsy was suggestive of CD 20 positive DLBCL and the patient received rituximab plus CHOP (Rituximab $375 \mathrm{mg} / \mathrm{m}^{2} \mathrm{IV}$ on day 1 plus CHOP) chemotherapy administered every 3 weeks. Before the third cycle of chemotherapy, she developed hoarseness of voice, difficulty in swallowing, and weakness of the left side of the face. Clinical examination revealed lower motor neuron type of unilateral left $7^{\text {th }}$ cranial nerve and bilateral $9^{\text {th }}$ and $10^{\text {th }}$ cranial nerve palsies. Magnetic resonance imaging showed no focal deposits of lymphoma. Cytological examination of cerebrospinal fluid showed the presence of atypical lymphoid cells suggestive of CNS involvement. The patient was administered triple intrathecal (methotrexate, cytosine arabinoside, and hydrocortisone) chemotherapy as per recommendations for her CNS disease. No cranial irradiation was given. The patient showed complete resolution of her CNS disease following further therapy. The subsequent clinical course was uneventful, and
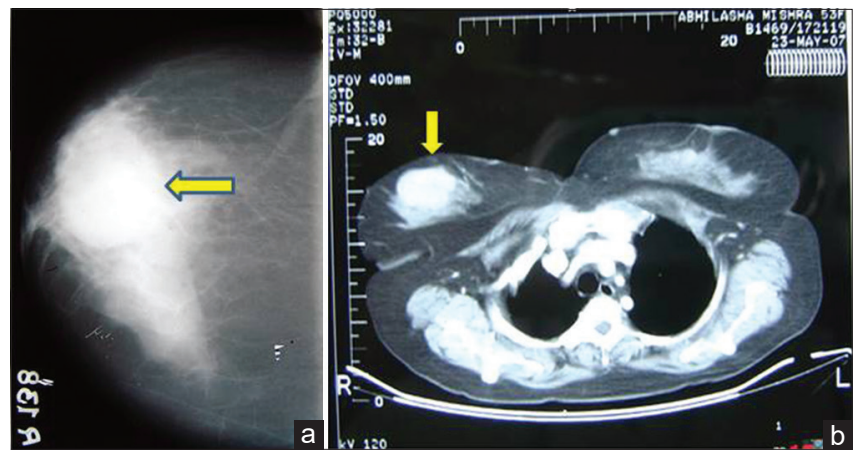

Figure 1: (a) Mammography of the right breast inpatient Case 2, shows smooth radiodense mass without spiculations or calcification. (b) Contrast-enhanced computed tomography of the thorax in the axial plane at the level of the breast in Case 2 shows enhance round mass lesion in the right breast

\begin{tabular}{|c|c|c|c|c|c|c|c|c|c|}
\hline $\begin{array}{l}\text { Case } \\
\text { number }\end{array}$ & $\begin{array}{c}\text { Age } \\
\text { (years) }\end{array}$ & $\begin{array}{c}\text { Year of } \\
\text { diagnosis }\end{array}$ & $\begin{array}{l}\text { Duration of } \\
\text { symptoms }\end{array}$ & $\begin{array}{l}\text { Site of } \\
\text { tumor }\end{array}$ & $\begin{array}{c}\text { Size of } \\
\text { tumor }(\mathrm{cm})\end{array}$ & Lymph nodes & $\begin{array}{c}\text { Performance } \\
\text { status } \\
\text { ECOG }\end{array}$ & $\begin{array}{c}\text { Ann arbor } \\
\text { staging }\end{array}$ & $\begin{array}{l}\text { Histological } \\
\text { subtype }\end{array}$ \\
\hline 1 & 66 & 2004 & 5 months & Left breast & $7 \times 6$ & $\begin{array}{l}\text { Single ipsilateral } \\
\text { axillary }\end{array}$ & 3 & IIE & DLBCL \\
\hline 2 & 52 & 2007 & 1 month & Right breast & $4 \times 2$ & Right axillary & 1 & IIE & DLBCL \\
\hline 3 & 50 & 2011 & 12 months & Right breast & $7 \times 5$ & Right axillary & 3 & IIE & ALCL \\
\hline
\end{tabular}

DLBCL - Diffuse large B-cell lymphoma; ALCL - Anaplastic large cell lymphoma; ECOG - Eastern Cooperative Oncology Group

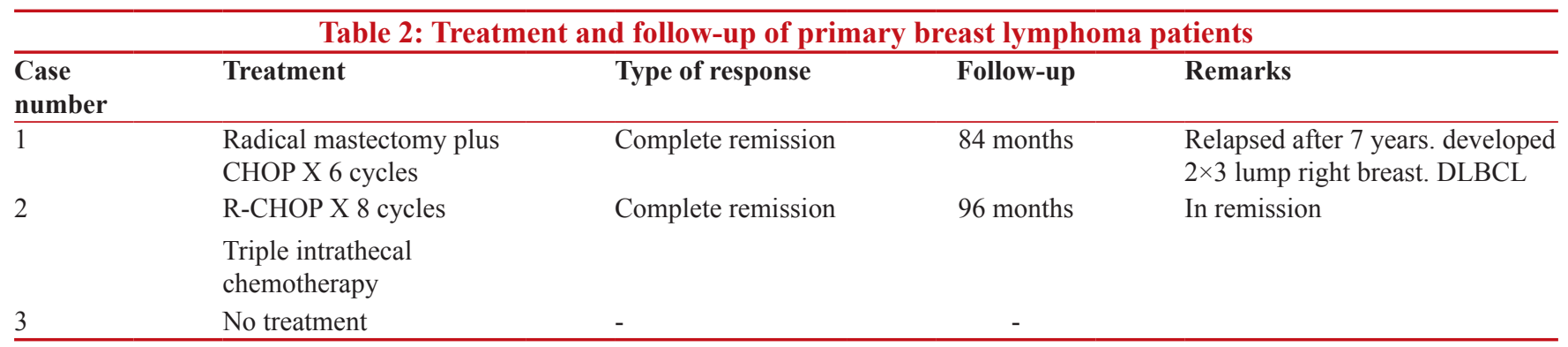




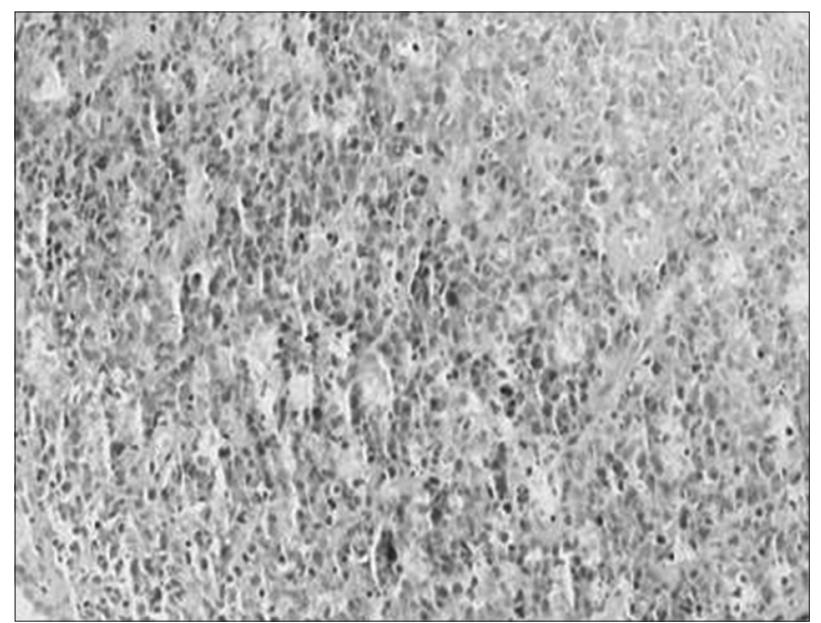

Figure 2: (Case 1) Diffuse large B-cell lymphoma. The sections show breast parenchyma with infiltration by sheets and cords of atypical lymphoid cells in a dense fibrocollagenous stroma. The cells display high $\mathrm{n} / \mathrm{c}$ ratio, round-to-oval nuclei, dispersed chromatin, and scant cytoplasm

the patient received a total of eight cycles of R-CHOP chemotherapy.

The third patient who was diagnosed to have ALCL of breast refused treatment for socioeconomic reasons.

\section{Follow-up and survival}

Both case 1 and 2 achieved CR following chemotherapy. Case 1 remained in disease-free state for the next 84 months of follow-up. In April 2011, the patient developed a new lump in the right breast measuring $2 \mathrm{~cm} \times 3 \mathrm{~cm}$ in size. A lumpectomy was performed, and the HPE was diagnostic of DLBCL. The patient was counseled for disease relapse; however, she refused further treatment. Case 2 remains in clinical remission for the last 96 months ( 8 years) of follow-up.

\section{Discussion}

PBL is a rare but potentially curable disease. The term PBL is used to define NHL occurring exclusively in the breast tissue with or without regional draining lymph node involvement and absence of any evidence of disease at another site. The disease usually occurs in the $5^{\text {th }}$ and $6^{\text {th }}$ decade of life and presents as a unilateral rapidly expanding painless mass. ${ }^{[9,10]}$ The right breast is more frequently involved 3:2 ratio. Bilateral breast involvement is seen in $6 \%$ to $11 \%$ of cases. ${ }^{[11]}$ The mass may be associated with local pain and signs of inflammation in up to $12 \%$ of patients. ${ }^{[9]}$

The pathogenesis of PBL is still not clear. It is postulated that the tumor arises from mucosa-associated lymphoid tissue (MALT). It may also develop from the lymphatic tissue present within the breast adjacent to ducts and lobules or from surrounding lymph nodes. ${ }^{[3,4]}$ Majority of the PBL are B-cell lymphomas and express CD 20 antigen. DLBCL is the most common histological type and accounts

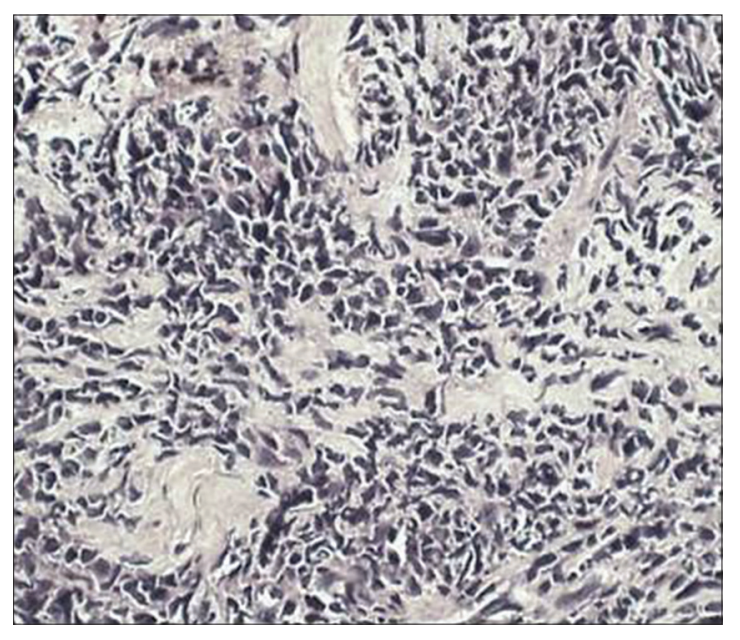

Figure 3: (Case 3) Diffuse large B-cell lymphoma. The section from the right breast lump shows diffuse sheet and cords of atypical lymphoid cells infiltrating the fibrocollagenous stroma. The tumor cells are round to irregular have moderately pleomorphic hyperchromatic nuclei and variable amount of cytoplasm, Mitotic figures are discernible

for $50 \%$ of all cases. Follicular lymphoma $15 \%$ and MALT $12.2 \%$ are the next frequent subtypes. ${ }^{[12]}$

On mammography, the tumor appears as oval shaped margins high-density mass without speculated margins or calcifications. ${ }^{[13]}$ Fine-needle aspiration cytology, tissue core, or excisional biopsy of the breast mass and draining lymph nodes are essential to establish the histopathological diagnosis. Bone marrow biopsy, CT of the thorax, and abdomen and positron emission tomography scan are required to rule out systemic NHL and for staging of disease.

Patients with PBL have been treated with radical mastectomy, chemotherapy, and radiotherapy either alone or in combination with varying results. Disease stage, tumor size, performance status, and IPI score influence the disease prognosis. ${ }^{[14]}$ Early-stage disease is associated with good prognosis and tumor size $>4 \mathrm{~cm}$ has an adverse prognosis. ${ }^{[9]}$

Ganjoo et al..$^{[1]}$ in a retrospective analysis of 37 patients with PBL found that DBL was the most common histologic subtype (49\%). Seventy percentage of the DLBCL patients were treated with doxorubicin-based chemotherapy and involved field radiotherapy (IFRT). The 5-year progression-free survival (PFS) was 61\% with median follow-up of 3.8 years and a 5-year overall survival (OS) was estimated at $82 \%$.

Ryan et $a l .{ }^{[14]}$ in a retrospective study of 204 patients with PBL (DLBCL subtype) attending the International ExtraNodal Lymphoma Study Group found that there was no benefit from mastectomy. Chemotherapy was associated with a median OS of 8.0 years and median PFS of 5.5 years. They concluded that limited surgery combined with chemotherapy and IFRT is associated with better outcome. 
Avilés et al..$^{[15]}$ in a prospective study of 96 patients with PBL compared treatment outcome with radiotherapy $(n=30)$, chemotherapy (CHOP-21 $\times 6$ cycles; $n=32$ ), and combined therapy (radiotherapy 30 Gy plus CHOP $\times 6$ cycles; $n=34)$. CR was observed in $66.71 \%(20 / 30)$ treated with radiotherapy, 59.4\% (19/30) with chemotherapy, and $88.2 \%(30 / 34)$ with combined modality. At 10 years median follow-up, the event-free survival was $50 \%, 57 \%$, and $83 \%$, respectively $(P<0.01)$ and the OS was $50 \%, 50 \%$ and $76 \%(P<0.01)$, respectively.

In a meta-analysis of 464 PBL cases diagnoses between 1972 and 2005, by Jennings et al., ${ }^{[13]}$ it was observed that $53 \%$ of all cases were of DLBCL subtype and the median age of presentation was 54 (range 17-95) years. Mastectomy showed no benefit regarding OS and recurrence rate. Radiotherapy showed benefit in survival and recurrence rates in Stage I patients. Chemotherapy showed benefit in Stage II patients. Rituximab is anti-CD 20 monoclonal antibody addition, of this agent with CHOP chemotherapy (R-CHOP), has shown high efficacy for DLBCL. Avilés et al. ${ }^{[16]}$ observed no CNS relapse in PBL patients treated with R-CHOP regimen compared to that $\mathrm{CHOP}$ regimen alone. THE CNS relapse rate was $11 \%$ in patients treated with CHOP regimen only. Sun et al. ${ }^{[17]}$ have observed that patients treated with rituximab plus chemotherapy have a superior 5-year PFS and local control. A study comparing the OS in patients with PBL and nodal DLBCL treated with R-CHOP and IFRT found no difference between the two groups. ${ }^{[18]}$

The role of CNS prophylaxis in PBL-DLBCL has been much debated A CNS relapse rate of $11.0 \%-17.6 \%$ has been reported in some studies. ${ }^{[15,19]}$ In contrast, other studies have reported a lower relapse rate of $4 \%$ to $5 \%$, which is similar to that observed in nodal DLBCL. ${ }^{[1,20]}$ Nearly $5 \%-14 \%$ has been observed in various retrospective studies. ${ }^{[9,14]}$ The present consensus is that PBL patients should be treated similar to nodal lymphoma of the same stage and histology. Anthracycline-based chemotherapy in combination with IFRT is the recommended modality of treatment. ${ }^{[6]}$

\section{Conclusion}

At our institute, both our PBL-DLBCL patients (Case 1 and 2) were treated with chemotherapy alone and had a DFS of 84 and 96 months, respectively. No CNS disease relapse or recurrence was observed in both our patients during the follow up period.

\section{Financial support and sponsorship}

Nil.

\section{Conflicts of interest}

There are no conflicts of interest.

\section{References}

1. Kim SH, Ezekiel MP, Kim RY. Primary lymphoma of the breast: Breast mass as an initial symptom. Am J Clin Oncol 1999;22:381-3.

2. Shapiro CM, Mansur D. Bilateral primary breast lymphoma. Am J Clin Oncol 2001;24:85-6.

3. Dao AH, Adkins RB Jr., Glick AD. Malignant lymphoma of the breast: A review of 13 cases. Am Surg 1992;58:792-6.

4. Zack JR, Trevisan SG, Gupta M. Primary breast lymphoma originating in a benign intramammary lymph node. AJR Am J Roentgenol 2001;177:177-8.

5. Wiseman C, Liao KT. Primary lymphoma of the breast. Cancer 1972;29:1705-12.

6. Cheah CY, Campbell BA, Seymour JF. Primary breast lymphoma. Cancer Treat Rev 2014;40:900-8.

7. Tavassoli FA, Devilee P. WHO Classification of Tumors: Pathological Genetics of Tumors of the Breast and Female Genital Organs. Lyon: IARC Press; 2003.

8. Carbone PP, Kaplan HS, Musshoff K, Smithers DW, Tubiana M. Report of the committee on Hodgkin's disease staging classification. Cancer Res 1971;31:1860-1.

9. Jeanneret-Sozzi W, Taghian A, Epelbaum R, Poortmans P, Zwahlen D, Amsler B, et al. Primary breast lymphoma: Patient profile, outcome and prognostic factors. A Multicentre Rare Cancer Network study. BMC Cancer 2008;8:86.

10. Wong WW, Schild SE, Halyard MY, Schomberg PJ. Primary non-Hodgkin lymphoma of the breast: The mayo clinic experience. J Surg Oncol 2002;80:19-25.

11. Ganjoo K, Advani R, Mariappan MR, McMillan A, Horning S. Non-Hodgkin lymphoma of the breast. Cancer 2007;110:25-30.

12. Jennings WC, Baker RS, Murray SS, Howard CA, Parker DE, Peabody LF, et al. Primary breast lymphoma: The role of mastectomy and the importance of lymph node status. Ann Surg 2007;245:784-9.

13. Lyou CY, Yang SK, Choe DH, Lee BH, Kim KH. Mammographic and sonographic findings of primary breast lymphoma. Clin Imaging 2007;31:234-8.

14. Ryan G, Martinelli G, Kuper-Hommel M, Tsang R, Pruneri G, Yuen K, et al. Primary diffuse large B-cell lymphoma of the breast: Prognostic factors and outcomes of a study by the International Extranodal Lymphoma Study Group. Ann Oncol 2008;19:233-41.

15. Avilés A, Delgado S, Nambo MJ, Neri N, Murillo E, Cleto S, et al. Primary breast lymphoma: Results of a controlled clinical trial. Oncology 2005;69:256-60.

16. Avilés A, Castañeda C, Neri N, Cleto S, Nambo MJ. Rituximab and dose dense chemotherapy in primary breast lymphoma. Haematologica 2007;92:1147-8.

17. Sun Y, Joks M, Xu LM, Chen XL, Qian D, You JQ, et al. Diffuse large B-cell lymphoma of the breast: Prognostic factors and treatment outcomes. Onco Targets Ther 2016;9:2069-80.

18. Yhim HY, Kim JS, Kang HJ, Kim SJ, Kim WS, Choi CW, et al. Matched pair analysis comparing the outcomes of primary breast and nodal diffuse B-cell lymphoma in patients treated with rituximab plus chemotherapy. Int J Cancer 2012;131:235-43.

19. Villa D, Connors JM, Shenkier TN, Gascoyne RD, Sehn LH, Savage KJ, et al. Incidence and risk factors for central nervous system relapse in patients with diffuse large B-cell lymphoma: The impact of the addition of rituximab to CHOP chemotherapy. Ann Oncol 2010;21:1046-52.

20. Ou CW, Shih LY, Wang PN, Chang H, Kuo MC, Tang TC, et al. Primary breast lymphoma: A single-institute experience in Taiwan. Biomed J 2014;37:321-5. 